\title{
"Reengineering support for competitive advantage through organizational basis, information and communication technology: a literature review"
}

\begin{tabular}{|c|c|}
\hline AUTHORS & $\begin{array}{l}\text { Agus Riyanto (D https://orcid.org/0000-0002-1781-7573 } \\
\text { R http://www.researcherid.com/rid/R-6500-2018 } \\
\text { Ina Primiana } \\
\text { Yunizar } \\
\text { Yudi Azis }\end{array}$ \\
\hline ARTICLE INFO & $\begin{array}{l}\text { Agus Riyanto, Ina Primiana, Yunizar and Yudi Azis (2018). Reengineering } \\
\text { support for competitive advantage through organizational basis, information and } \\
\text { communication technology: a literature review. Problems and Perspectives in } \\
\text { Management, 16(3), 464-476. doi:10.21511/ppm.16(3).2018.37 }\end{array}$ \\
\hline DOI & http://dx.doi.org/10.21511/ppm.16(3).2018.37 \\
\hline RELEASED ON & Saturday, 22 September 2018 \\
\hline RECEIVED ON & Thursday, 17 May 2018 \\
\hline ACCEPTED ON & Thursday, 09 August 2018 \\
\hline LICENSE & $\begin{array}{l}(c) \text { EY-No } \\
\text { This work is licensed under a Creative Commons Attribution-NonCommercial } 4.0 \\
\text { International License }\end{array}$ \\
\hline JOURNAL & "Problems and Perspectives in Management" \\
\hline ISSN PRINT & $1727-7051$ \\
\hline ISSN ONLINE & $1810-5467$ \\
\hline PUBLISHER & LLC "Consulting Publishing Company "Business Perspectives" \\
\hline FOUNDER & LLC "Consulting Publishing Company "Business Perspectives" \\
\hline
\end{tabular}

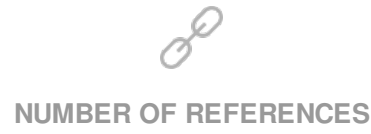

47
NUMBER OF FIGURES

10
NUMBER OF TABLES

1

(C) The author(s) 2022. This publication is an open access article. 


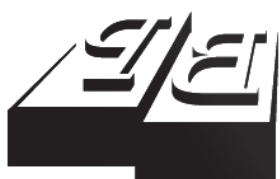

BUSINESS PERSPECTIVES

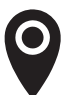

LLC “CPC "Business Perspectives" Hryhorii Skovoroda lane, 10, Sumy, 40022, Ukraine

www.businessperspectives.org

Received on: $17^{\text {th }}$ of May, 2018 Accepted on: $9^{\text {th }}$ of August, 2018

(C) Agus Riyanto, Ina Primiana, Yunizar, Yudi Azis, 2018

Agus Riyanto, Doctoral Student of Science and Management, Universitas Padjadjaran; Lecturer, Universitas Komputer, Indonesia.

Ina Primiana, Lecturer of Doctoral Science and Management, Universitas Padjadjaran, Indonesia.

Yunizar, Lecturer of Doctoral Science and Management, Universitas Padjadjaran, Indonesia.

Yudi Azis, Lecturer of Doctoral Science and Management, Universitas Padjadjaran, Indonesia.

\section{(ㄷ)(1) (8)}

This is an Open Access article, distributed under the terms of the Creative Commons Attribution-NonCommercial 4.0 International license, which permits re-use, distribution, and reproduction, provided the materials aren't used for commercial purposes and the original work is properly cited.
Agus Riyanto (Indonesia), Ina Primiana (Indonesia), Yunizar (Indonesia),

Yudi Azis (Indonesia)

\section{REENGINEERING SUPPORT} FOR COMPETITIVE ADVANTAGE THROUGH ORGANIZATIONAL BASIS, INFORMATION AND

\section{COMMUNICATION TECHNOLOGY:} A LITERATURE REVIEW

\begin{abstract}
This research is intended to collect and investigate the previous research that is related to reengineering with Business Process Reengineering (BPR) in manufacturing industry to achieve a "competitive advantage". The purpose of this study is to provide a general overview of the relationship between BPR variables, competitive advantage variables, organizational commitment variables, organizational change management variables, information and communication technology variables, which are supported by IDEF0 method.
\end{abstract}

This research overall uses secondary data sources from a research published in a journal and proceeding for the variables of BPR, competitive advantage, organizational commitment, organizational change management, information and communication technology, which is supported by IDEF0 method.

This study is limited to the existing research subject that was in online media and the specific purpose is to review a progress in the BPR, which is mainly based on organization, information technology and engineering. The previous researches concluded that there were influencing variables toward BPR, which is related to competitive advantage.

\section{Keywords}

business process reengineering, competitive advantage, organization, information and communication technology

\section{JEL Classification M15, M21}

\section{INTRODUCTION}

In the early 1990's, the term of Business Process Reengineering (BPR) was already known to the business world in America since its introduction by Hummer (1993). Business Process Reengineering was not only used in the manufacturing industry but also in the business sector for the service industry. Hammer was the first person to introduce the name of business process reengineering and he was considered as the father of business process reengineering. BPR was earlier considered as a tool to bring drastic changes to business processes and was adopted by an American Company, which focused on the private sector, in the early 1990's as a substitute for the use of total quality management (TQM), an improved method which was developed in Japan. BPR can be mentioned as a new approach for the organizations that require process management to bring drastic changes in the organizational performance.

The current competition is not only occurring regionally but also globally. The organizations seek to improve competitive advantage to deal with major changes, one of which can be done by conducting business 
process reengineering, they redesign business process drastically. Besides, there is a problem that most of the organizations that implement business process reengineering as their main focus fail to implement BPR (Ramanigopal et al., 2011).

Nowadays this change occurs in every sector, such as transportation sector, and is implemented by online, online shops (e-commerce) such as Amazon.com and financial technology like the emergence of fintech in the world. The rapid change of information technology will be a commercial arena that gives a birth to organizational change. Organizations must restructure and redefine their business strategies to solve this major change. BPR is a popular management tool for dealing with a rapid technological and business changes (Ozcelik, 2010; Ranganathan et al., 2011). Beside that success, the research of AlMashari et al. (2011) and Chiplunkar et al. (2003) illustrates that up to 70\% of BPR failure occurs at the implementation stage. It is caused by the lack of understanding of management within an organization.

The failure of BPR occurred at the implementation process (procedures, processes, management) stage, infrastructure (information technology facilities, technology), human error (leadership, employees), company characteristics (size and type of business) or the combination of them (Smith et al., 2013).

To solve these problems, the main purpose of this study is to provide a general overview of the relationship between BPR variables, competitive advantage variables, organizational commitment variables, organizational change management variables, information and communication technology variables, which is supported by IDEF0 method based on previous researches and proceeding.

\section{LITERATURE REVIEW}

\subsection{Competitive advantage}

Competitive advantage is very important for a company, because it shows its performance. It is a company position for the competitors. According to Porter (1998), there are two methods to create a competitive advantage. The first is saving of cost that will make a cost advantage, it occurs when a company provides the same service as its competitors at a lower cost. The second is the differentiation, this advantage occurs when a company provides a larger service at the same price as its competitors. This is overall known as a position advantage, because it shows the company's position in its industry as a leader in service or superior cost.

The company has the advantages through resources and capabilities that are superior for the competitors. Then, as long as the company applies a strategy that utilizes these resources and capabilities effectively, so it is possible to create a competitive advantage. This is achieved through the plan and management strategy, which is an ongoing process that evaluates, controls and checks business, competitors and industry overall. Moreover, it is necessary to set a goal and a strategy to overcome the obstacles in achieving success (Nimsith et al., 2016).

Competitive advantage can be described as a management concept that has been so popular in contemporary management literature. The reason behind this popularity is due to the rapid change that must be faced by a company today. The complexity of the business environment, the impact of globalization and an unstructured market, consumer needs, competition, revolution of information and communication technology and global trade continuously change (Moghli et al., 2012).

Porter (1998) considered that the competitive advantage is a corporate activity through flexibility, product or service supply, on time, cost efficiency and owned differentiation value, which can increase business performance toward competitors. Ferreira and Kittsteiner (2012) said that competitive advantage can be developed by a model where competitive pressure will become a stimulation for organizational changes. Competitive advantage can be through a business strategy based on differentiation, coordination and focus. According to Markiewicz (2011), a strategy process is influenced by the organization, innovation, creativity and perception. 
Kasasbeh et al. (2017) explained that competitive advantage can be reached by a concept related to business process reengineering that will make the organization a leader toward competitors in its sector. Specifically, this is a stock of the organization that will make a profit in a competitive market. The dimensions of competitive advantage can be found through service quality, organization growth, performance, marketing innovation, creativity, customer orientation and market differentiation.

\subsection{Business process reengineering}

BPR is a set of management activities that replaces the traditional one and establishes a reasonable business process through optimization, employee authorization, customer suggestion and the application of information and communication technology. BPR replaces the traditional labor-sharing system and emphasizes the direction of work and process creating some new management principles for the business company (Ringim et al., 2013).

The failure of business process reengineering implementation was discussed by Altinkemer et al. (1998). There were two out of 35 companies that failed to implement business process reengineering. But both were aimed at successful BPR implementation after they did process repairing. Subramanian et al. (1999) had the same opinion that $50-70 \%$ support for reengineering was unable to bring dramatic changes.

Ramanigopal (2011) defined BPR as an available modern tool to manage the change for the purpose of BPR that can redesign and change existing business practices and processes to achieve an organization performance improvement dramatically. Ringim et al. (2013) said that BPR is defined as a complete and radical process transformation, which changes bureaucratic structure within the organization for core process specialization.

\subsection{Organizational commitment}

Organizational commitment in the BPR implementation is very influential to achieve the success of the company (Osano \& Okwena, 2015). Every business process that has been undertaken and committed to the management is properly communicated to all elements within the organization.
This will make the implementation of BPR in progress can run well.

\subsection{Organizational change management}

Nzewi Hope et al. (2015) and Ringim et al. (2013) say that one of the factors affecting the BPR is organizational change management. Redesigning the entire process from the old approach to a newer one needs to be improved to achieve better performance due to changes in government policies and competition that exists today.

\subsection{Information and communication technology}

Osano and Okwena (2015) describe the BPR as the aspect that leads to a change and introduces new processes and a new working style, so that certain elements needed to make a change. Among them is the management of information technology (IT) that cannot be ignored for a radical redesign of an organization.

\subsection{IDEF0 model}

IDEF0 model (Integration Definition Language 0), is an SADT-based (Structure Analysis and Design Technique) system modelling method developed by Douglas T. Ross and SofTech, Inc. In its original form, IDEF0 includes a definition language and graphical modelling (syntax and semantics) that describes a comprehensive methodology for model building. IDEF0 (Integration Definition language 0 ) is a modelling language that uses images with a comprehensive explanation to explain the development stages or methodology of a system. The system is modelled as a group of functions that are interconnected with one another to form a major function. These functions describe what is done by the system, so anything that is controlled, processed, and generated by the system can be known (Clarence, 1998).

\section{METHODOLOGY}

This research uses qualitative methods by looking at the literature review of some journals, as well as by looking at secondary data coming from the internet, reports and review journals. In order to 


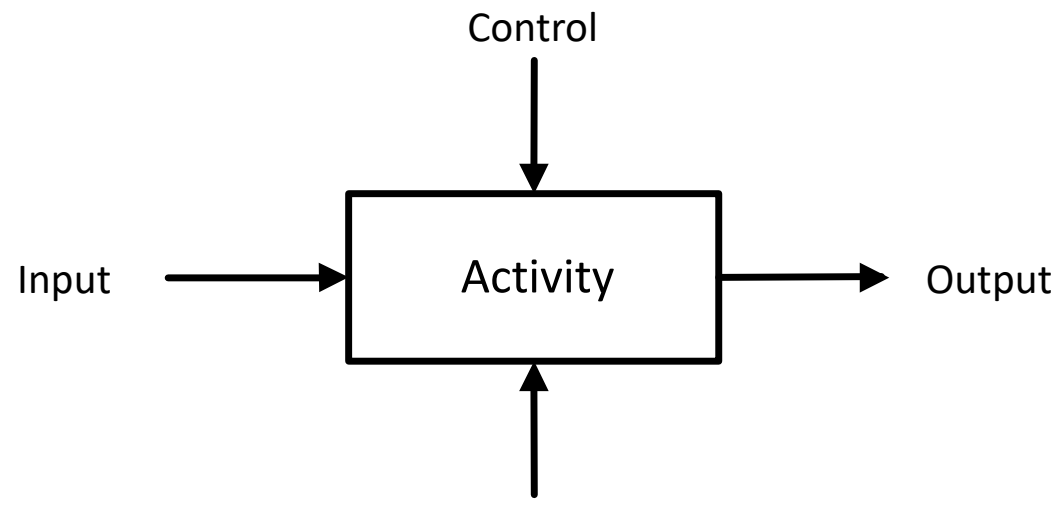

Mechanism

Figure 1. Building blocks in the IDEF0 model

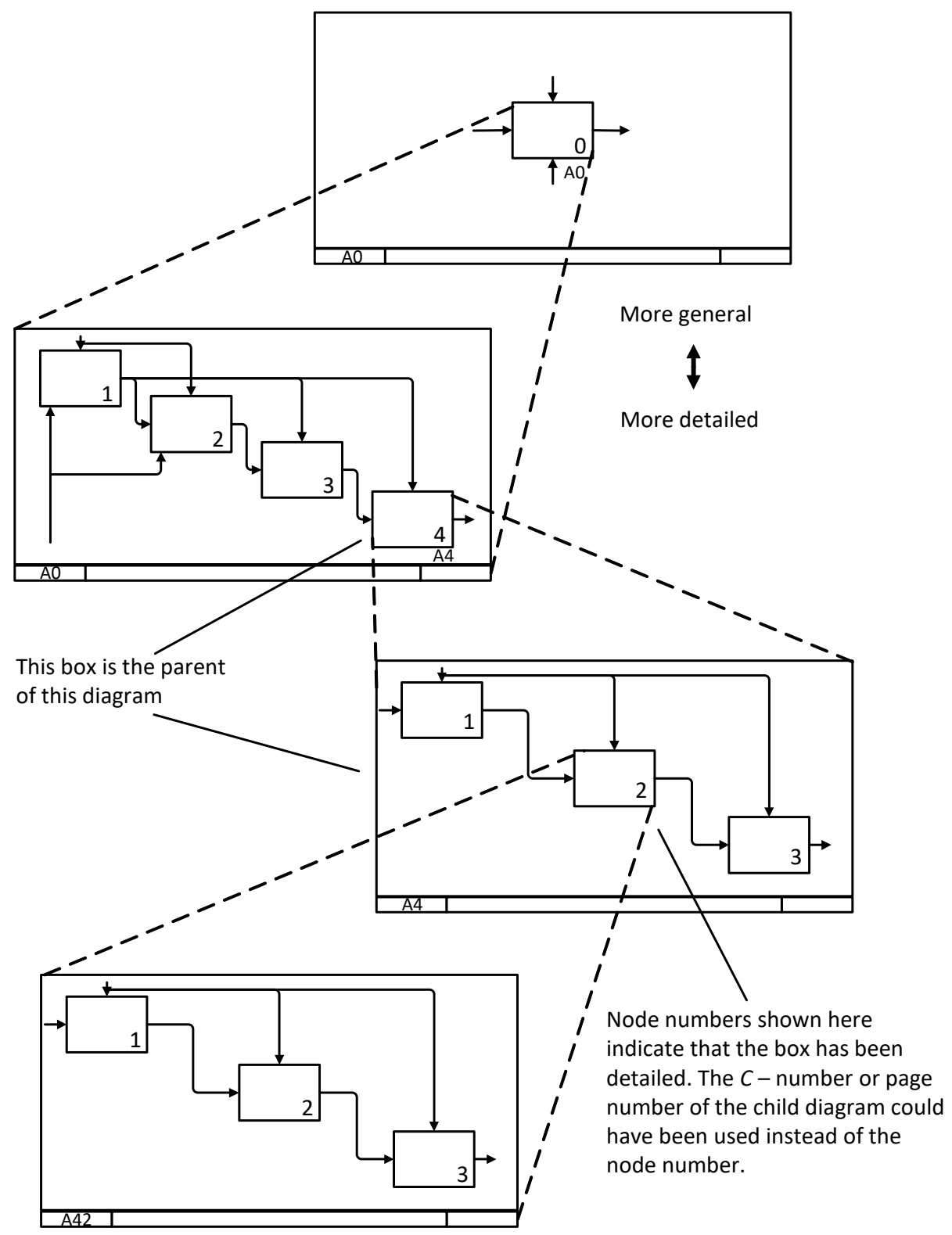

Figure 2. Decomposition in IDEFO 
achieve a competitive advantage, every organization is required to conduct BPR. A radical business change will inevitably have to be done in the face of disruptive innovation. BPR implementation will be successful if supported in terms of an organization that is organizational commitment and organizational change management. In terms of technology platform implementation, business process reengineering must develop information and communication technology (ICT).

To support the BPR implementation, it can be done by developing the business process using IDEF0 model. The IDEF0 model for the business process will be shown as building blocks activity (see Figure 1).

IDEF0 considers a system as a collection of activities that use ICOM (Input-Control-OutputMechanism) to embody its function. Activity and ICOM is a constituent component of the system that must be identified the model (Tsironis et al., 2008). In other words, the model of a system using the IDEF0 method is a depiction of the activity and ICOM of a system as in Figure 2.

\section{RESULTS AND DISCUSSION}

The failure rate of the BPR implementation is large. The success of BPR is supported by organizational commitment, organizational change management and understanding of technology, especially information and communication technology (ICT).

\subsection{Organizational commitment relationship toward business process reengineering}

Jurisch et al. (2016) stated that organizational commitment affects the performance of business change and process performance. The study by Mlay (2013) shows that $81 \%$ of employees believe in and agree to the implementation of business process reengineering, the others are still in doubt. This result shows that there is a great commitment of employees to the implementation of business process reengineering, similar to the result of this study, the study of Goksoy et al. (2012) showed $85.4 \%$ agreed to commitment and leadership support for the business process reengineering implementation.

To understand easily the relationship between the organizational commitment and business process reengineering, see Figure 3.

Three results of the study above show that there is a mutual interaction between organizational commitment and business process reengineering. It can be concluded that organizational commitment influences business process reengineering.

\subsection{Organizational commitment relationship toward competitive advantage}

The previous research showed that there is a relationship between an organizational commitment and a competitive advantage. The research of Zangene-Tabar (2013) explained that research findings based on structural equation model show that the quality of an organizational commitment has a significant effect on customer orientation as part of competitive advantage. The study of Savaneviciene (2012) explains that organizational commitment is the goal of human management based on quality and flexibility, which is the dimension of competitive advantage. And the research of De Brentani and Kleinschmidt (2004) also explained that organizational commitment and organizational culture are strongly influenced by new product development as part of superior product.

Juisch et al. (2016)

Mlay et al. (2013)

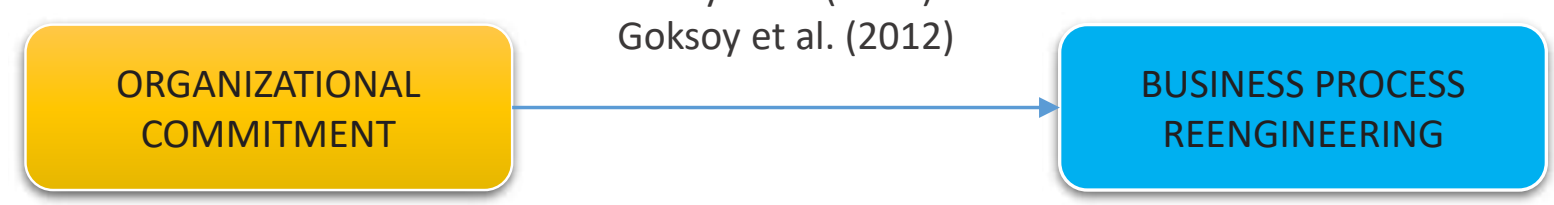

Figure 3. Organizational commitment relationship toward business process reengineering 
Zangene-Tabar et al. (2013)

Savaneviciene et al. (2012)

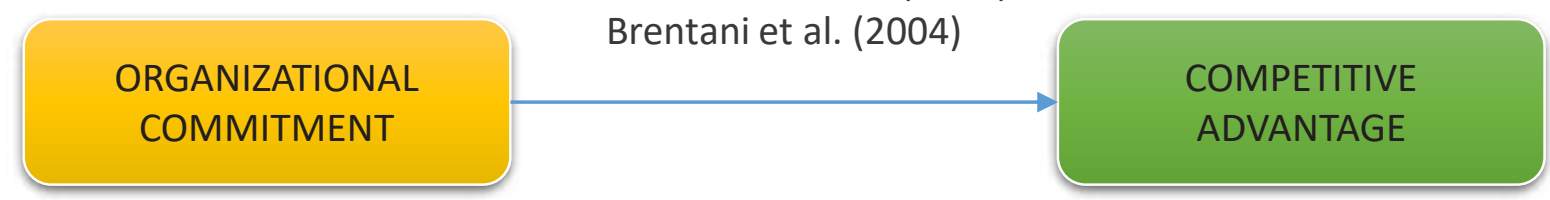

Figure 4. Organizational commitment relationship toward competitive advantage

The relationship between the organizational commitment and competitive advantage is presented in Figure 4.

The results show that there is a relationship between the organization commitment and competitive advantage. Therefore, it can be concluded that an organization commitment has an effect on competitive advantage.

\subsection{Organizational change management relationship toward business process reengineering}

The previous research said that there is a relationship between organizational change management and BPR. In research of Mlay (2013) it is stated that the organizational commitment, organizational change management and information technology have a great effect on BPR. The research of Anand et al. (2009) explained that an organizational change that occurred in five companies requires continuous process improvement as a potential dynamic ability within an organization. Furthermore, AlMashari et al. (2001) point out that the success of BPR implementation is associated with a methodological use. Organizational change management is an area that needs to be methodologically handled by researchers. This case also shows that diagnosing the current process is an important BPR stage, and it is a difficult task for an organization to implement it. It also shows the importance of commitment and process implementation of BPR. Similarly, Altinkemer (1998) explained that the organization requires a change in order to improve organizational performance, and the changes will occur when BPR is implemented.

The relationship between the organizational change management and BPR is presented in Figure 5.

According to four opinions above, there is a mutual influence between organizational change management and BPR. It can be concluded that the organizational change management has an effect on BPR.

\subsection{Organizational change management relationship toward competitive advantage}

There is a relationship between the organizational change management and competitive advantage. The research of Tudor Liviu and Bisa Christian (2015) explained that the organizational change management is a very important organizational competitive advantage. Thus, it can ensure organization's progress and facilitate a better performance than competitors. The study of Fok Yew Oon and Hartini (2014) said that the organizational change management had a strong effect toward operational advantage. The research of

Mlay et al. (2013)

Gopesh et al. (2009)

Al-Mashari et. al. (2001)

ORGANIZATIONAL

CHANGE MANAGEMENT

Altinkemer et al. (1998)

Figure 5. Organizational change management relationship toward business process reengineering 
Tudor Liviu et al. (2015)

Fok et al. (2014)

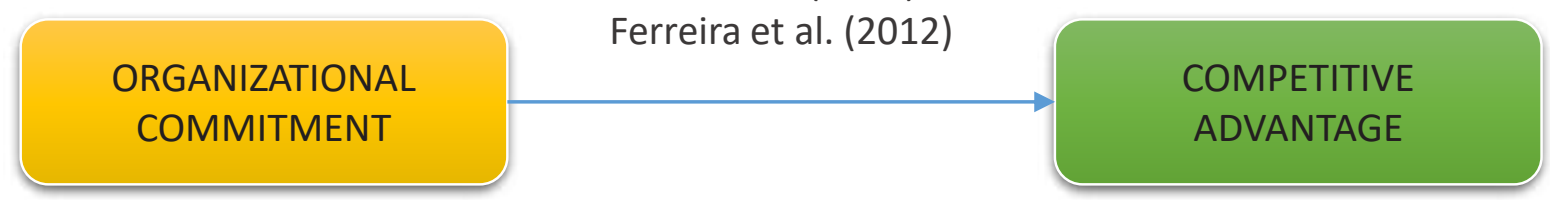

Figure 6. Organizational change management relationship toward competitive advantage

Ferreira and Kittsteinner (2012) explained that the business strategy model is a catalyst for an organizational change. A simple business strategy is invaluable because an employee needs to coordinate his efforts to build strategic capabilities as a competitive advantage.

To understand easily the relationship between the organizational change management and competitive advantage see Figure 6.

The opinions above indicate a relationship between the organizational change management and competitive advantage. It can be concluded that the organizational change management has an effect on competitive advantage.

\subsection{Information and communication technology relationship toward business process reengineering}

In the previous section, it was said that there is a relationship between the information and communication technology and the BPR. Huang et al. (2014) revealed that the information and communication technology has a strong relationship toward the BPR and performance. The study of Mlay et al. (2013) explained that organizational commitment, organizational change management and information and communication technology have a positive effect on BPR. Maroofi et al. (2013)'s research described that the information and communication technology has a strong influence on the BPR, internal business processes, organization, customer satisfaction and financial performance. The study of Anand et al. (2009) explained how the learning theory informs the theory of continuous improvement and allows to see such improvement as a dynamic ability in the organization through an information technology. The research of Shin and Jemella (2002) explained that BPR can be applied in a bank by using four variables. They are process, organization, finance, information and communication technology. Davenport and Short (1990) described that the information and communication technology has a major influence on the business process redesign.

To understand easily the relationship between the information and communication technology and BPR, see Figure 7.

The seven opinions above indicate that there is a relationship between the information and communication technology and BPR. So, it can be concluded that the information and communication technology has an effect toward BPR.

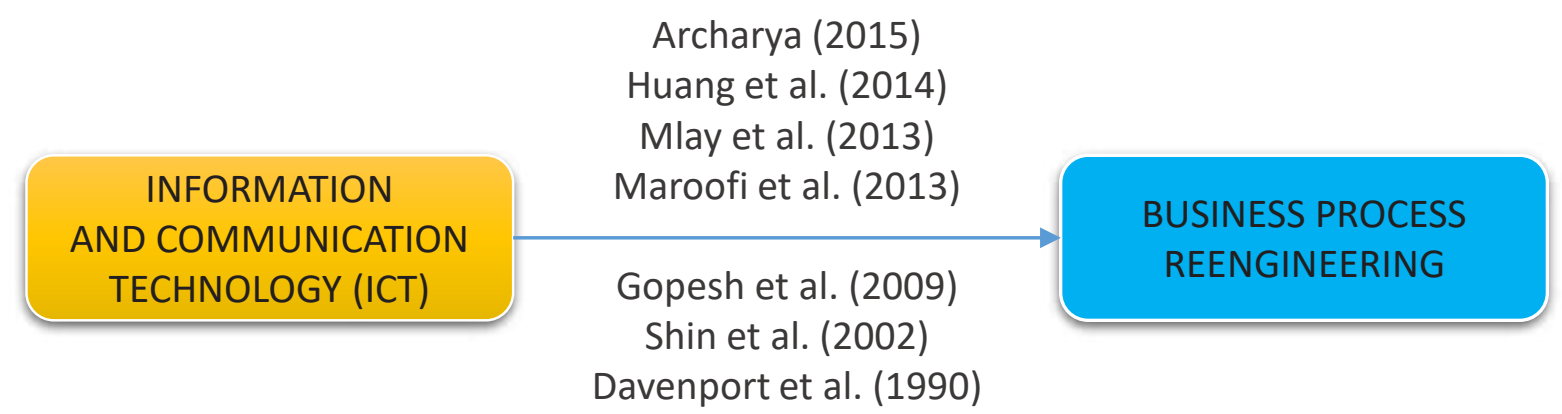

Figure 7. The information and communication technology relationship toward business process reengineering 


\subsection{Information and communication technology relationship toward competitive advantage}

In the previous research it was said that there is a relationship between information and communication technology and competitive advantage. Patroba et al. (2016) explained that the information and communication technology through investment, risk management and operation has a strong influence toward competitive advantage. Similarly, Chi and Sun (2015) said that the competitive advantage is influenced by the information and communication technology through process, source and impact of information technology. Breznik (2012) revealed that the competitive advantage can occur when the information and communication technology is implemented. The study of Ong (2008) explained that the information and communication technology through knowledge, operation and object has a strong influence toward competitive advantage. Similarly, Vargas, Hernandez, and Bruque (2003) explained that the implementation of the information and communication technology has a strong influence toward competitive advantage through organizational performance. Human, management and technology have a strong influence on the competitive advantage through information technology function.

To understand easily the relationship between the information and communication technology and competitive advantage, see Figure 8.

The five studies above showed that there is a mutual influence between information and communication technology and competitive advantage. And finally, it can be concluded that the information and communication technology has an effect toward competitive advantage.

\subsection{Business process reengineering relationship toward competitive advantage}

Some previous studies showed that there is a relationship between BPR and competitive advantage. The research of Saeed and Nasar (2016) explained that Pakistani commercial banks are required to implement continuous improvement process in realizing the process of bank system, and to adjust themselves in focusing on the existing finance and trends at the international level to enlarge the competitive advantage. The study of Huang et al. (2014) explained that the information and communication technology has a strong influence toward performance as a competitive advantage. The research of Wang et al. (2012) said that the bank system process is a good management model to be implemented in China to build a modern commercial bank through an information technology. Then, Aregbeyen (2011) explained that the failure to review the implementation of BPR in Nigeria is because a decline occurred in the organizations' performance during 10 years. The study of Adeyemi and Aremu (2008) explained that an organization's performance is strongly influenced by process, quality and strategy as a dimension of competitive advantage. Similarly, Peterson et al. (2010) explained that the implementation of BPR can provide added value in the form of competitive advantage for Wrigley's company.

To understand easily the relationship between the BPR and competitive advantage, see Figure 9.

Finally, the opinions of researches above showed that there is a relationship between BPR and competitive advantage. So it can be concluded that BPR has an effect toward competitive advantage.

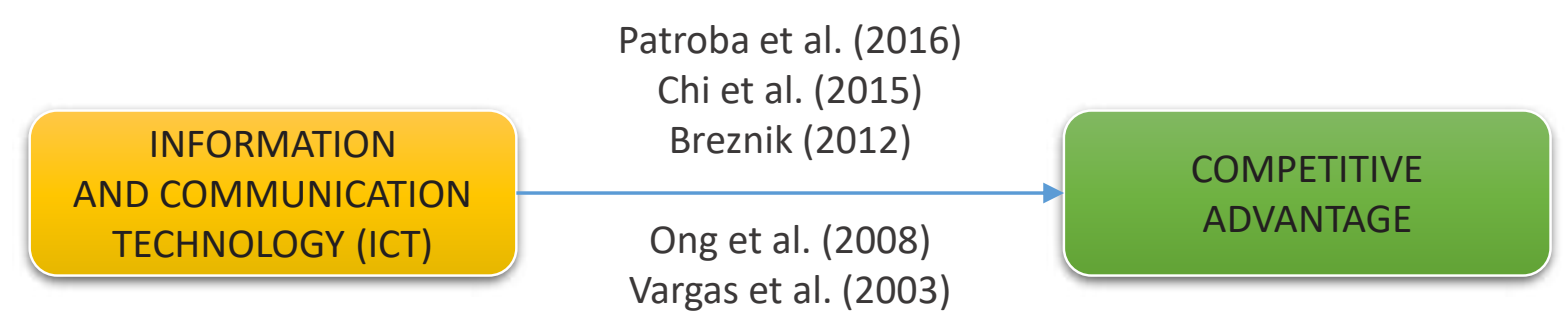

Figure 8. The information and communication technology relationship toward competitive advantage 
Saeed et al. (2016)

Huang et al. (2014)

Wang et al. (2012)

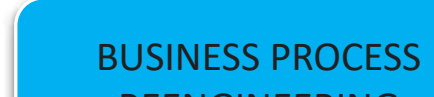

Aregbeyen (2011)

Magutu et al. (2010)

Sidikat et al. (2008)

Prasetyana (2005)

Kovacic (2000)

Figure 9. Business process reengineering relationship toward competitive advantage

Table 1. The research of all variables

\begin{tabular}{|c|c|c|c|c|c|c|c|c|}
\hline No. & Writer, year & 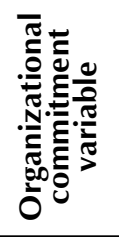 & 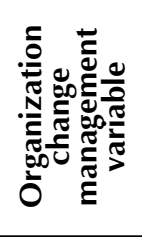 & 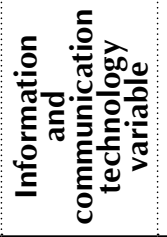 & $\begin{array}{l}\frac{0}{\frac{0}{0}} \\
\frac{\pi}{\frac{\pi}{\frac{\pi}{2}}} \\
\frac{0}{0}\end{array}$ & 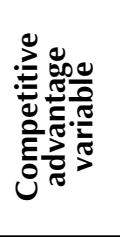 & IDEF0 & Method \\
\hline 1 & Jurisch et al. (2015) & $\sqrt{ }$ & - & - & - & - & - & Quantitative, PLS \\
\hline 2 & Mlay et al. (2013) & $\sqrt{ }$ & $\sqrt{ }$ & $\sqrt{ }$ & - & - & - & $\begin{array}{c}\text { Qualitative, SPSS, } \\
\text { EView3 and Excel } \\
2007\end{array}$ \\
\hline 3 & Goksoy et al. (2012) & $\sqrt{ }$ & - & $\sqrt{ }$ & $\sqrt{ }$ & - & - & $\begin{array}{c}\text { Quantitative, } \\
\text { Regression analysis }\end{array}$ \\
\hline 4 & Tabar et al. (2013) & $\sqrt{ }$ & - & - & - & $\sqrt{ }$ & - & Quantitative, SEM \\
\hline 5 & $\begin{array}{l}\text { Savaneviciene et al. } \\
(2012)\end{array}$ & $\sqrt{ }$ & - & - & - & $\sqrt{ }$ & - & $\begin{array}{c}\text { Quantitative, } \\
\text { Qualitative }\end{array}$ \\
\hline 6 & Brentani et al. (2004) & $\sqrt{ }$ & - & - & - & $\sqrt{3}$ & - & Quantitative, AMOS \\
\hline 7 & Anand et al. (2009) & $\sqrt{ }$ & $\sqrt{ }$ & $\sqrt{ }$ & $\sqrt{ }$ & - & - & $\begin{array}{l}\text { Quantitative, } \\
\text { Qualitative }\end{array}$ \\
\hline 8 & Shin et al. (2002) & - & $\sqrt{ }$ & $\sqrt{ }$ & $\sqrt{ }$ & - & - & Qualitative \\
\hline 9 & Al-Mashari et al. (2001) & - & $\sqrt{ }$ & - & $\sqrt{ }$ & - & - & Qualitative \\
\hline 10 & Altinkemer et al. (1998) & - & $\sqrt{ }$ & - & $\sqrt{ }$ & - & - & Qualitative \\
\hline 11 & Tudor et al. (2015) & - & $\sqrt{ }$ & - & - & $\sqrt{ }$ & - & Quantitative \\
\hline 12 & Fok et al. (2014) & - & $\sqrt{ }$ & - & - & $\sqrt{3}$ & - & Quantitative, SPSS \\
\hline 13 & Ferreira et al. (2012) & - & $\sqrt{ }$ & - & - & $\sqrt{ }$ & - & Quantitative \\
\hline 14 & Markiewicz (2011) & - & $\sqrt{3}$ & - & - & $\sqrt{1}$ & - & Qualitative \\
\hline 15 & Huang et al. (2014) & - & - & $\sqrt{3}$ & $\sqrt{ }$ & $\sqrt{ }$ & - & Quantitative \\
\hline 16 & Maroofi et al. (2013) & - & - & $\sqrt{ }$ & $\sqrt{ }$ & - & - & Quantitative, AMOS \\
\hline 17 & Davenport et al. (1990) & - & - & $\sqrt{ }$ & $\sqrt{ }$ & - & - & Qualitative \\
\hline 18 & Prasetyana (2005) & - & - & & $\sqrt{ }$ & - & - & Qualitative \\
\hline 19 & Ellitan (1999) & $\sqrt{ }$ & $\sqrt{ }$ & $\sqrt{3}$ & $\sqrt{ }$ & - & - & Qualitative \\
\hline 20 & Acharya (2005) & - & - & $\sqrt{ }$ & $\sqrt{ }$ & - & - & Quantitative, SPSS \\
\hline 21 & Waiganjo et al. (2012) & - & - & & - & $\sqrt{3}$ & - & Qualitative \\
\hline 22 & Patroba et al. (2016) & - & - & $\sqrt{ }$ & - & $\sqrt{ }$ & - & Quantitative, SPSS \\
\hline 23 & Chi et al. (2015) & - & - & $\sqrt{ }$ & - & $\sqrt{ }$ & - & Qualitative \\
\hline 24 & Breznik (2012) & - & - & $\sqrt{3}$ & - & $\sqrt{ }$ & - & Qualitative \\
\hline 25 & Bulatovic et al. (2011) & - & - & $\sqrt{ }$ & - & - & - & Qualitative \\
\hline 26 & Ong (2008) & - & - & $\sqrt{ }$ & - & $\sqrt{ }$ & - & Quantitative \\
\hline 27 & Vargas et al. (2003) & - & - & $\sqrt{3}$ & - & $\sqrt{ }$ & - & Quantitative \\
\hline 28 & Saeed et al. (2016) & - & - & - & - & $\sqrt{ }$ & - & Qualitative \\
\hline 29 & Wang et al. (2012) & - & - & - & - & $\sqrt{ }$ & - & Qualitative \\
\hline
\end{tabular}


Table 1 (cont.). The research of all variables

\begin{tabular}{|c|c|c|c|c|c|c|c|c|}
\hline No. & Writer, year & 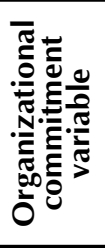 & 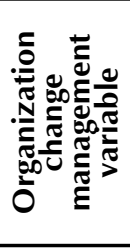 & 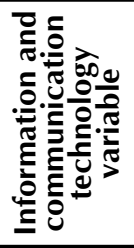 & $\begin{array}{l}\frac{0}{0} \\
\frac{0}{\frac{0}{2}} \\
\frac{\pi}{\frac{0}{0}} \\
\frac{0}{0}\end{array}$ & 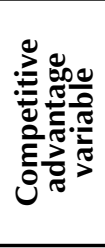 & IDEF0 & Method \\
\hline 30 & Aregbeyen (2011) & - & - & - & $\sqrt{ }$ & $\sqrt{ }$ & - & Qualitative \\
\hline 31 & Sidikat et al. (2008) & - & - & - & $\sqrt{ }$ & $\sqrt{ }$ & - & Quantitative \\
\hline 32 & Magutu et al. (2010) & - & - & - & $\sqrt{ }$ & $\sqrt{ }$ & - & Quantitative \\
\hline 33 & Allen et al. (1993) & $\sqrt{ }$ & - & - & - & - & - & $\begin{array}{l}\text { Quantitative, } \\
\text { MANOVA }\end{array}$ \\
\hline 34 & Xiaoli (2010) & - & - & - & $\sqrt{ }$ & $\sqrt{ }$ & - & $\begin{array}{c}\text { Quantitative, SEM, } \\
\text { SPSS, Lisrel }\end{array}$ \\
\hline 35 & Sarkis et al. (1995) & - & - & - & - & - & $\sqrt{ }$ & Qualitative \\
\hline 36 & Min et al. (1996) & - & - & - & $\sqrt{ }$ & - & $\sqrt{ }$ & Qualitative \\
\hline 37 & Dachyar et al. (2016) & - & - & - & $\sqrt{ }$ & - & $\sqrt{ }$ & Qualitative \\
\hline
\end{tabular}

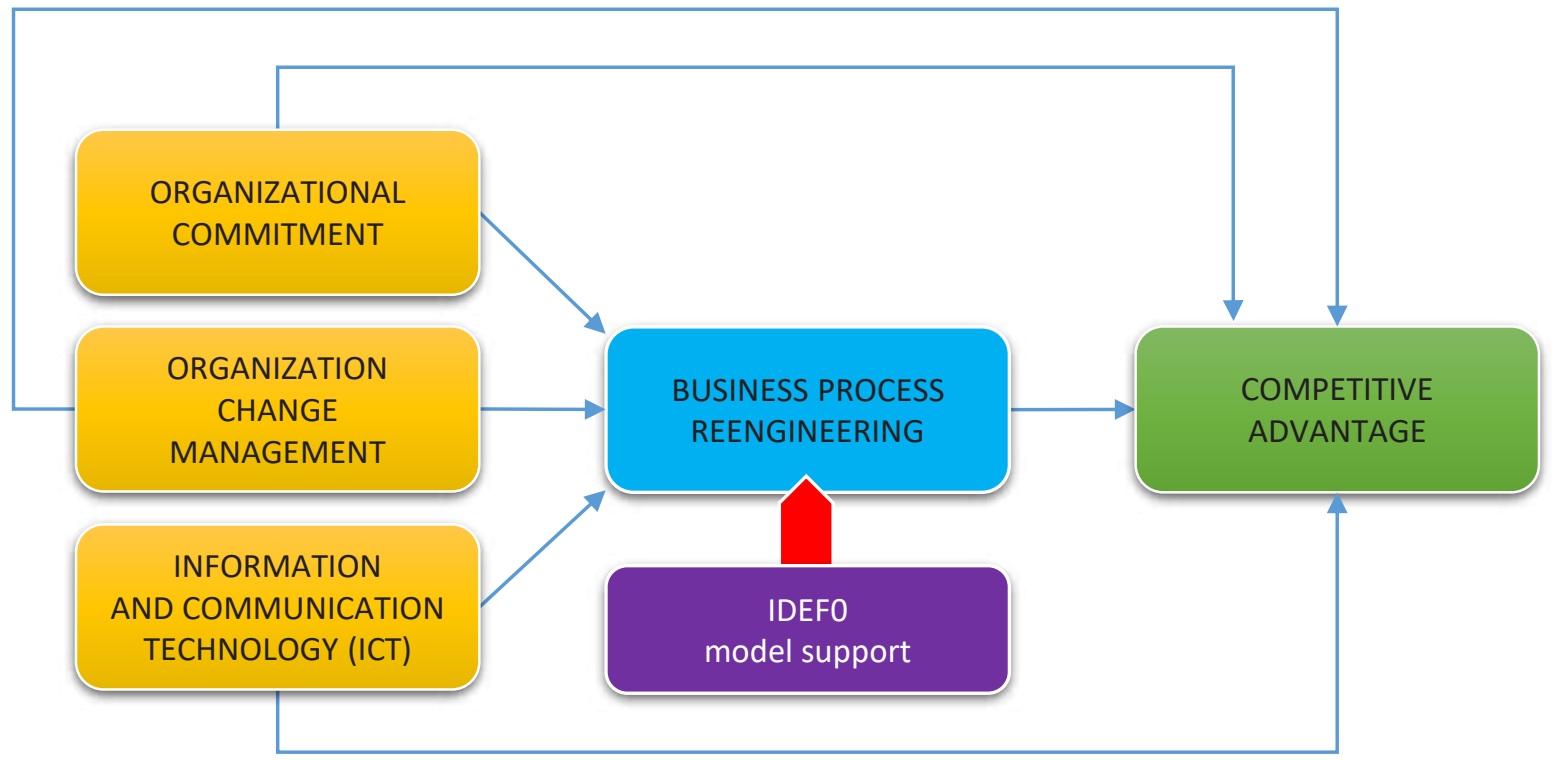

Figure 10. Paradigm model

Yiven the relationship between each variable that has a mutual influence, then in Figure 10 a model can be seen that describes the relationship and the influence between each variable contained in a paradigm model that is developed and sought for the influence of these variables.
Based on previous studies, a paradigm model can be developed for the manufacturing industry or service industry in the implementation of BPR to improve future competitive advantage.

\section{CONCLUSION}

The previous research or proceedings showed that the variables of competitive advantage, business process reengineering, organizational commitment, organizational change management and information and communication technology have interrelated relations. To be able to compete under the global changes, an organization must have a competitive advantage. This competitive advantage occurs by BPR implementation through the organizational change. In order to be successful in the BPR implementa- 
tion, an organization must have an organizational commitment (from top to bottom level), organizational change management (vision, mission and strategy), capability and availability of information and communication technology.

IDEF0 model is one of the ways to support BPR. A process change due to a replacement from a traditional process to a technology-based one can be described by IDEF0 that explains the process order based on the hierarchy activity. For each building, blocks consist of input: something that is transformed by an activity; control: something that determines how an activity occurs but is not transformed by it; output: something that is produced by the activity; and mechanism: people, facilities, machines, or others that run the activities.

\section{REFERENCES}

1. Adeyemi, S., \& Aremu, A. M. (2008). Impact Assessment of Business Process Reengineering on Organisational Performance. European Journal of Social Sciences, 7(1), 115-125. Retrieved from https://pdfs.semanticscholar.org/ eb90/9f23c754fd109b13fa343da6c 2e5e27bb90c.pdf

2. Allen, N. J., \& Meyer, J. P. (1993). Organizational Commitment: Evidence of Career Stage Effects? Journal of Business Research, 26(1), 49-61. https://doi. org/10.1016/0148-2963(93)90042 $\mathrm{N}$

3. Al-Mashari, M., Irani, Z., \& Zairi, M. (2001). Business Process Reengineering: A Survey of International Experience. Business Process Management Journal, 7(5), 437-455. Retrieved from http:// citeseerx.ist.psu.edu/viewdoc/dow nload?doi $=10.1 \cdot 1.456 .391 \& \mathrm{rep}=\mathrm{re}$ $\mathrm{p} 1 \&$ type $=\mathrm{pdf}$

4. Altinkemer, K., Chaturvedi, A., \& Kondareddy, S. (1998). Business Process Reengineering and Organizational Performance: An Exploration of Issues. International Journal of Information Management, 18(6), 381-392. Retrieved from http:// isiarticles.com/bundles/Article/ pre/pdf/440.pdf

5. Anand, G., Ward, T. P., Tatikonda, M., \& Schilling, A. D. (2009). Dynamic Capabilities thought Continuous Improvement Infrastructure. Journal of Operations Management, 27(6), 444-461. https://doi.org/10.1016/j. jom.2009.02.002
6. Aregbeyen, O. (2011). Business Re-Engineering and Organisational Performance in Nigeria: A Case Study of First Bank Nigeria Pic. International Business Management, 5(3), 151158. https://doi.org/10.3923/ ibm.2011.151.158

7. Azzam Azmi Abou-Moghli, Ghaith Mustafa Al Abdallah, \& Ayed Al Muala (2012). Impact of Innovation on Realizing Competitive Advantage in Banking Sector in Jordan. American Academic \& Scholarly Research Journal, 4(5). Retrieved from www.naturalspublishing. com/files/published/i5883cn9tb27t4.pdf

8. Breznik, L. (2012). Can Information Technology Be a Source of Competitive Advantage? Economic and Business Review, 14(3), 251-269. Retrieved from http://ojs.ebrjournal.net/ojs/index. php/ebr/article/viewFile/167/pdf

9. Chi, J., \& Sun, L. (2015). IT and Competitive Advantage: A Study from Micro Perspective. Modern Economy, 6(03), 404-410. https:// dx.doi.org/10.4236/me.2015.63038

10. Chiplunkar, C., Deshmukh, S., \& Chattopadhyay, R. (2003). Application of principles of event related open systems to business process reengineering. Computers \& Industrial Engineering, 45(3), 347-374. https://doi.org/10.1016/ S0360-8352(03)00029-9

11. Davenport, H. T., \& Short, E. J. (1990). The New Industrial Engineering: Information
Technology and Business Process Redesign. Sloan Management Review, 31(4), 11-27. Retrieved from http://is.ieis.tue.nl/education/bpmcourse/papers/Davenport $\% 20 \% 281990 \% 29 \% 20-\% 20$ The $\% 20$ New\%20Industrial $\% 20$ Engineering.pdf

12. De Brentani, U., \& Kleinschmidt, J. E. (2004). Corporate Culture and Commitment: Impact on Performance of International New Product Development Programs. The Journal of Product Innovation Management, Product Development and Management Association, 21, 309-333. https://doi.org/10.1111/j.07376782.2004.00085.x

13. Feldmann, C. G. (1998). The Practical Guide to BPR Using IDEFO. NY: Dorset House Publisher.

14. Ferreira, D., \& Kittsteinner, T. (2012). Competition and Organizational Change. CRES Foundations of Business Strategy Conference. Washington University. Retrieved from http://www.mikrooekonomie. rwth-aachen.de/workingpaper/ Competition_and_Organizational_Change.pdf

15. Fok-Yew Oon, \& Hartini, A. (2014). The Effect of Change Management on Operational Excellence Moderated by Commitment to Change: Evidance from Malaysia. International Journal of Innovation and Applied Studies, 9(2), 615631. Retrieved from http://www. ijias.issr-journals.org/abstract. php?article=IJIAS-14-268-02 
16. Goksoy, A., Ozsoy Beliz, \& Vayvay Ozalp (2012). Business Process Reengineering: Strategic Tool for Managing Organizational Change an Application in a Multinational Company. International Journal of business and Management, 7(2). Published by Canadian Center of science and Education.

17. Grover, V., Kettinger, W. J., \& Teng, J. T. C. (1995). The Implementation of BPR. Journal of Management Information System, 12(1), 109-144. https://doi.org/10.1 080/07421222.1995.11518072

18. Hall, G., Rosenthal, J., \& Wade, J. (1993). How to make Reengineering Really Work. Harvard Business Review, NovDec., 191-131. Retrieved from https://hbr.org/1993/11/how-tomake-reengineering-really-work

19. Huang, S. Y., Lee Hsiung Chao, \& Chiu An-An (2014). How Business Process Reengineering Affects Information Technology Investment and Employee Performance Under Different Performance Measurement. Information Systems Frontiers, 17(5), 1133-1144. https://doi. org/10.1007/s10796-014-9487-4

20. Jurisch, M. C., Rosenberg, Z., \& Krcmar, H. (2015). Emergent Risk in Business Process Change Projects. Business Process Management Journal, 22(4), 791-811. https://doi.org/10.1108/ BPMJ-01-2015-0002

21. Kasasbeh, E. A., Harada, Y., \& Noor, I. M. (2017). Factors Influencing Competitive Advantage in Banking Sector: A Systematic Literature Review. Research Journal of Business Management, 11(2), 67-73. https://dx.doi.org/10.3923/ rjbm.2017.67.73

22. Markiewicz, P. (2011). Change Management in The Strategy Implementation Process. Intellectual Economics Journal, 5(2), 257-267. Retrieved from https://www.mruni.eu/upload/ iblock/e15/MARKIEWICZ.pdf

23. Maroofi, F., Kahrarian, F., \& Dehghani, M. (2013). Evaluation of The Effect of Using Information Technology Infrastructure for
Business Process Reengineering in Small and Medium Sized Entreprises of Kermanshah Province. International Journal of Academic Research in Business and Social Sciences, 3(9), 404416. http://dx.doi.org/10.6007/ IJARBSS/v3-i9/229

24. Masumi, M. (2013). The CSFs, Quality Governance, BPR Performance and Gaining Competitive Advantage. International Journal of Business and Management, 8(24), 18338119. http://dx.doi.org/10.5539/ ijbm.v8n24p48

25. Mlay, V. S., Zlotnikova, I., \& Watundu, S. (2013). A Quantitative Analysis of Business Process Reengineering and Organizational Resistance: The Case of Uganda. The African Journal of Information Systems, 5(1). Retrieved from https://digitalcommons.kennesaw.edu/cgi/viewcontent. cgi article $=1116 \&$ context $=$ ajis

26. Muthu Subramanian, Whitman, L., \& Cheraghi, H. (1999). Business Process Reengineering: A Consolidated Methodology. Proceeding of the $4^{\text {th }}$ Annual International Conference on Industrial Engineering Theory, Applications and Practice. San Antonio, Texas, USA. Retrieved from https://pdfs.semanticscholar. org/c790/28e18c12be231acbdda3f ef5855a6f8224d7.pdf

27. Nimsith, S. I., Rifas, A. H., \& Cader, M. J. A. (2016). Impact of Core Competency on Competitive Advantage of Banking Firms in Sri Lanka. International Journal of Scientific Research and Innovative Technology, 3(7), 64-72. Retrieved from https://www.ijsrit.com/ uploaded_all_files/1475528331_ m6.pdf

28. Ong, W. J. (2008). Sustainable Competitive Advantage through Information Technology Competence: Resource-Based View on Small and Medium Enterprises. Communications of the IBIMA, 1. Retrieved from http://citeseerx.ist.psu.edu/viewdoc/download?doi=10.1.1.411.328 $8 \&$ rep $=$ rep $1 \&$ type $=$ pdf
29. Osano, M. H., \& Okwena, D. (2015). Factors Influencing Performance of Business Process Reengineering Projects in Banks in Kenya: Case of Kenya Commercial Bank. Journal of US-China Public Administration, 12(11), 833-844. http://dx.doi.org/10.17265/15486591/2015.11.002

30. Ozcelik, Y. (2010). Do business process reengineering projects payoff? Evidence from the United States. International Journal of Project Management, 28(1), 7-13. http://dx.doi.org/10.1016/j.ijproman.2009.03.004

31. Patroba, M. M., Osoro, K., Nyagol, M., \& Odoyo, F. (2016). Influence of Information Technology in Enhancement of Sutainable Advantage of Saccos in Kisii County. IOSR Journal of Humanities and Social Science, 21(3), 103-117. Retrieved from http://www.iosrjournals.org/iosrjhss/papers/Vol.\%2021\%20Issue3/ Version-1/O210301103117.pdf

32. Peterson, M., Onserio, S., \& Kiplmo. G. (2010). Business Process Reengineering for Competitive Advantage. Key Factors That May Lead to Success or Failure of the BPR Implementation (The Wrigley Company). African Journal of Business \& Management, 1, 135150. Retrieved from http://www. uonbi.ac.ke/conferences/aibuma/ journal/Paper11_Business_Process_Reengineering.pdf

33. Porter, E. M. (2008). Competitive Advantage: Creating and Maintaining Superior Performance. Jakarta: Karisma Publishing Group.

34. Ramanigopal, C. S., Palaniappan, G., Hemalatha, N., \& Murugan,

T. (2011). Business Process Reengineering and Its Applications. International Journal of Management Research and Review, 1(5), 275-288. Retrieved from http://ijmrr.com/admin/ upload_data/journal_full $\% 20 \% 20$ \%2018.pdf

35. Ranganathan, C., Teo, T. S., \& Dhaliwal, J. (2011). Web-enabled supply chain management: Key antecedents and performance 
impacts. International Journal of Information Management, 31(6), 533-545. https://doi.org/10.1016/j. ijinfomgt.2011.02.004

36. Reger, R. K., Mullane, L. T., Gustafson, L. T., \& DeMarie, S. (1994). Creating Earthquakes to Changes Organizational Mindsets. Academy of Management Executive, 8(4), 31-42. https://doi. org/10.5465/ame.1994.9412071701

37. Ringim, K. J., Osman Nor Hasni, Hasnan Norlena, \& Razalli Mohd Rizal (2013). Exploring the Implementation of Business Process Reengineering in Banks. Asian Social Science, 9(11), 243253. https://doi.org/10.5539/ass. v9n11p243

38. Saeed, M. S., \& Nasar, A. (2016). Continous Process Improvement (CPI) in Pakistani Banking Sector for Improving Overall Performance. Journal of Business \& Financial Affairs, 5(3). Retrieved from https://www. omicsonline.org/open-access/ continuous-process-improvement-cpi-in-pakistani-bankingsecto-r-forimproving-overall-performance-2167-0234-1000210. pdf

39. Savaneviciene, A., \& Stankeviciute, Z. (2012). Human Resource Management and Performance: From Practices Towards Sustainable Competitive Advantage. InTech Globalization - Educationand Management Agendas. Chapter 8. https://dx.doi. org/10.5772/47800
40. Shin, N., \& Jemella, F. D. (2002) Business Process Reengineering and Performance Improvement the Case of Chase Manhattan Bank. Business Process Management Journal Emerald, 8(4), 351-363. https://dx.doi. org/10.1108/14637150210435008

41. Zangene-Tabar, M., Falahati, A., \& Moradi, A. (2013). The Effect of Quality Commitment and Organizational Commitment on The Customer Orientation (Case Study: Kermanshah Tejarat Bank). International Research Journal of Applied and Basic Science: Science Explorer Publications, 4(10), 3146-3153. Retrieved from https:// docplayer.net/48809315-Theeffect-of-quality-commitmentand-organizational-commitmenton-the-customer-orientation-casestudy-kermanshah-tejarat-bank. html

42. Thomas, O. O. (2014). Change Management and Its Effects on Organizational Performance of Nigerian Telecoms Industries: Empirical Insight from Nigeria. International Journal of Humanities Social Sciences and Education (IJHSSE), 1(11), 170-179. Retrieved from https://www.arcjournals.org/ pdfs/ijhsse/v1-i11/18.pdf

43. Todnem, Rune (2005). Organisational Change Management: A Critical Review. Journal of Change Management, 5(4), 369-380. https://dx.doi. org/10.1080/14697010500359250
44. Tsironis Loukas, Gentsos Andreas, \& Moustakis Vassilis (2008). Empowerment The IDEF0 Modeling Language. International Journal of Business and Management, 3(5). Retrieved from https://www.researchgate. net/publication/41891191_Empowerment_the_IDEF0_modeling_language

45. Tudor Liviu, \& Bisa Christian (2015). Change Management as a Competitive Advantage for Romanian Companies. Proceedings of the $9^{\text {th }}$ International Management Conference. Retrieved from http://conferinta. management.ase.ro/archives/2015/ pdf/16.pdf

46. Vargas, A., Hernandez, M. J., \& Bruque, S. (2003). Determinants of Information Technology Competitive Value Evidence from a Western European Industry. Journal of High Technology Management Research 14: Elsevier Science Inc., 245-268. Retrieved from https://www. uhu.es/alfonso_ vargas/archivos/ JHTMRarticle.pdf

47. Wang, L., Herve, G. D., \& Shen, Y. (2012). Continuous Process Improvement in Banking Sector and a Model Design for Performance Enhancement. International Journal of Business and Management, 7(2), 130-141. Retrieved from https://pdfs.semanticscholar.org/4111/0cf619766 7f3310782137a27b9abfe931ef1.pdf 